\title{
BIOLOGICAL ASPECTS OF ACARID MITE, TYROPHAGUS NEISWANDERI REARED UNDER LABORATORY CONDITIONS ON TWO FOOD TYPES
}

\author{
A.M. Metwally ${ }^{(1)}$, A.A. AbdAllah ${ }^{(1)}$, Hala M. Gamal El- Din ${ }^{(2)}$, M.M. El Moghazy ${ }^{(1)}$, \\ Amany A. El-Sadawy ${ }^{(2)}$ \\ (1) Agric. Zoology and Nematology Dept. Faculty of Agriculture, Alazhar University. \\ (2) Biological and Environmental Science Dept. Fac. Home Economic, Tanta, Alazhar University.
}

Received: Oct. 4, 2016

Accepted: Oct. 15,2016

\begin{abstract}
This work was conducted to determine the effect of yeast and processed meat (lanshon) as food source on the biology of the acarid mite, Tyrophagus neiswanderi under laboratory conditions of $28 \pm 2{ }^{\circ} \mathrm{C}$ and $65 \% \mathrm{RH}$. The results showed that the longevity period was significantly different between the two food types. Yeast treatment had significantly high generation time with average 22.45 days, while in the salted fresh meat showed significantly shorter longevity time with average 21.15 days. Furthermore, there were significant differences between the two food types in daily rate of eggs per female. Yeast treatment exhibited higher average daily rate of eggs recorded 13.65 egg, compared with 11.21 egg at salted fresh meat.
\end{abstract}

Key words: Biology; Tyrophagus neiswanderi; Generation time; Daily rate

\section{INTRODUCTION}

Mites are so vary in their feeding habits, some are phytophagous, pests of stored products, predators, animal parasites and free livings. However, mites significantly affect the agriculture, food, health and physical comfort of our society. Many of these mites cause problems to poultry and farm animals, either by feeding on their blood, tissue fluids and burn owing in the skin, or by transmitting serious diseases. Consequently, meat, milk and egg production is affected. Thus mites associated with poultry are considered today a major problem in poultry industry. The poultry red mite, Dermanyssus gallinae, is an example of poultry parasite that also injurious to man. It was recorded on domestic fowl, pigeons, and other birds (Abo-Taka and Allam, 1997).

Other mites develop complex parasitic relationship with both vertebrates and invertebrates. In recent years, there has been an increasing awareness of dermatitis in man and domestic animals. People who work in poultry farm'; or wild agricultural animals such as color birds in captivity, as well as those work with stored food products are at times aware of mites infesting these materials and producing an irritating itch. For example, Ornithonyssus sylviarum mite spend the majority of their life cycle on the avian host but may be transmit to man as a result of direct contact and also through air borne spread (Orton et al., 2000).

The damage caused by mites can result in decreased farm production such as egg, the fall in productive cycle of the hens, lower weight gain, anemia, exhaustion, and even death (Kilpinen et al., 2005). SanchezRamos and Castanera (2007) evaluated the effect of physical conditions on reproduction and capacity of increase of the populations of Tyrophagus neiswanderi to elucidate their role in the differential abundance found in the maturing caves. Additionally, the study of the effect of temperature can be used to establish the thermal developmental thresholds, which are very useful to develop sound pest management programs based on modifications of temperature.

The objective of this study was to determine the effect of yeast and processed meat (lanshon) on the biology of the acarid mite Tyrophagus neiswanderi under laboratory conditions. 


\section{MATERIALS AND METHODS}

Mite species were collected from litter, feather samples of chickens, ducks, pekeeny ducks, geese, rabbits (domestic animals) quails, and poultry food from Sakha, Nasr City, Tanta and Qotor along two successive years. For obtaining pure culture of females and males, collected adults were placed in the rearing plastic blocks (2 cm long $\times 2 \mathrm{~cm}$ diameter wide) filled with a mixture of (Cement: Charcoal in ratio 9: 1) as a substrate. The rearing plastic for each mite species contained yeast and a drop of water as a source of food and humidity, then the cell covered to prevent mite from escaping. Thirty blocks were used for each species. Each replicate contained a singly newly deposited egg which transferring by using of a fine camel brush (00). Thirty replicates were investigated twice daily under a standard binocular microscope. During each investigation add a drop of water in each block. The different biological aspects (incubation period, hatching, moulting, mating, (active and quiescent) larvae, protonymph, tritonymph, adult female and male were investigated, and recorded emergence males and females were sexed and then separated for testing the longevity and adult-hood of females and males respectively. A single female and male were placed together, to notice the mating behavior and calculated the life cycle, generation time, fecundity and life span, by counting the number of eggs laid every day. Mite species were reared on yeast under laboratory condition $26 \pm 2^{0} \mathrm{C}$ and $70 \%$ R.H.

Statistical analysis of obtained data was conducted using Proc ANOVA and GLM in SAS (SAS Institute 1998). Mean separation was conducted using Duncan Multiple Range Test in the same program.

\section{RESULTS AND DISCUSSION Developmental duration:}

There are four immature developmental stages characteristic of acarids: egg, larva, protonymph and tritonymph. The larvae are active, slightly larger than the eggs, and have three pairs of legs. The nymphs (protonymph and tritonymp) are larger than larvae and have four pairs of legs. They look similar to adults, which in turn are larger than the nymphs. No mortality of immature stages was recorded when fed on yeast.

\section{Incubation period:}

Table (1) shows the duration of immature stage. Lasted for 3.18 and 3.56 days for female, while it was 2.86 and 3.30 days for male at $\left(30^{\circ} \mathrm{C}\right.$ and $60 \% \pm 15 \mathrm{R} . \mathrm{H}$ when it fed on yeast and lanshon respectively.

Our previous data showed that there were no significant differences between the different food types.

\section{Larval stage:}

The average period of active larva lasted for 2.80 and 3.01 days for female, while it was 2.63 and 2.86 days for male when it fed on yeast, lanshon respectively at $\left(30^{\circ} \mathrm{C}\right.$ and $60 \% \pm 15 R . H)$.

The average period of quiescent stage lasted 1.10and1.28days for female and 0 . 70 and 1.20 for male at $\left(30^{\circ} \mathrm{C}\right.$ $60 \pm 15$ R.H).When the individuals fed on yeast, lanshon respectively.

The total larval periods were 3.89and 4.29 days for female, while they were 3.33 and 4.06 for male when they fed on the previous diets, respectively.

The differences between the larval stages were no significant between male and female when they fed on lanshon, but it was significant when they feed on yeast, the highest period was when the mite fed on lanshon while the less period was when the mite fed on yeast.

\section{Protonymphal stage:}

The active female protonymph lasted for 2.96 and 3.01 days, while the quiescent stage lasted for 1.01 and 1.31 days at $\left(30^{\circ} \mathrm{C}\right.$ and $60 \% \pm 15$ R.H.) when the individuals fed on yeast and lanshon, respectively. 
The active male protonymph lasted 2.73 and 3.00 days, while the quiescent stage lasted 0.73 and 1.20 days at the same trend, the total protonymph period was 3.98 and 4.33 days for female, while it was 3.46 and 4.16 days for male at the same trend.

The previous data showed that were no significant differences between male and female when they fed on lanshon but it was significant when the mite fed on yeast .

\section{Tritonymphal stage:}

The active female tritonymphal stage occupied 2.95 and 3.01days, while the quiescent stage occupied 1.10 and 0.85 days at $\left(30^{\circ} \mathrm{C}\right.$ and $60 \% \pm 15 \mathrm{R} . \mathrm{H}$.) but the active male tritonymph occupied 2.66 and 3.03 days the quiescent stage lasted 0.70 and 1.36 days at $\left(30^{\circ} \mathrm{C}\right.$ and $60 \% \pm 15$ R.H $)$, when the individuals fed on yeast and lanshon respectively .The total tritonymphal period were 4.05 and 3.86 days for female, while they were 3.36 and 4.39 days for male at the same trend. From the previous data there was significant differences between the food types.

\section{Immature stage :}

The female total immature which included, larva, protonymph and tritonymph stages lasted 11.92 and 12.48 while these of males lasted 10.14 and 12.64 days at $\left(30^{\circ} \mathrm{C}\right.$ and $60 \% \pm 15$ R.H ) when the individuals fed on yeast and lanshon respectively.

In general, the time required for female immature stage was longer than the male immature stage between different tested food types and the differences was significant when they fed on yeast, but it was no significant when the mite feed on lanshon .

\section{Life cycle:}

The period of life cycle (which included, incubation,larval,protonymphal, tritonymphal stage ) was completed on 16.51 and 16.5 days for females, which it was 13.01 and 15.94 days for males at $\left(30^{\circ} \mathrm{C}\right.$ and $60 \%$ \pm 15 R.H) when the individuals fed on yeast and lanshon respectively.

In general it can be concluded that the feeding on lanshon gave the longest life cycle, also, it was significantly when they fed on yeast but it was no significantly when they fed on lanshon different between the food types .

\section{Specific female stages:}

The preoviposition, generation, oviposition and postoviposition period were an averaged $2.65,17,75,16.90,2.90$ days , respectively when fed on yeast at $\left(30^{\circ} \mathrm{C}\right.$ and $60 \% \pm 15$ R.H) while they were $2.60,18.65$ ,15.75, 2.80 days respectively when fed on lanshon.

The female deposition on averaged 13.65 and 11.21 egg for day, when the individuals fed on yeast and lanshon respectively. The previous data showed that there were significant differences between the effects of the food types in generation, but there was no significant in oviposition, postoviposition and preoviposition .

\section{Longevity :}

The longevity period lasted on averaged for 22.45 and 21.15 days for female, while it was 25.1 and 25.5 days $f$ or male at $\left(30^{\circ} \mathrm{C}\right.$ and $60 \% \pm 15 R . H$ ) There were significant differences between the effects of food types between male and female.

\section{Life span:}

The life span (which included the period of life cycle and longevity ) averaged 37.55 and 37,20 for female while it was 38.11 and 41.44 for male at $\left(30^{\circ} \mathrm{C}\right.$ and $60 \%$ $\pm 15 \mathrm{R} . \mathrm{H}$ ) when the individuals fed on yeast and respectively.

In general ,the time required for female life cycle was longer than the male, while the time required for female longevity and life span were shorter than these of male at different food and the differences was no significant .

The survival curves of the mite under laboratory conditions followed a type I 
Metwally, et al.,

pattern in which most eggs developed to maturity and death occurred gradually over an extended ovipositional period (Figure 1). The number of Tyrophagus neiswanderi survival declined on day $32^{\text {nd }}$ and ended on day 38when feed on lanshon. Females started laying eggs on the day 18and reached to the highest rate on the 26 day after that the eggs started to decrease until the thirty eight day then the females stopped laying eggs. But the survival declined on day 30th and ended on day 42th and the females started laying eggs on the day 15th and reached to the highest rate on the 26 th day after that the eggs started to decrease until the day of 38th then the females stopped laying eggs when feed on yeast.

\section{Total average number of eggs:}

There were significant differences between different female food. Total average number of eggs 288.20 egg and with a daily rate $13.65 \mathrm{egg} / \mathrm{day} / \mathrm{female}$, and 175.35 egg with a daily rate 11.21 egg/day/female, when fed on yeast and lanshon (Table, 2).

Table (1): Developmental time of different stages of Tyrophagus neiswanderi fed on yeast and lanshon at $\left(26 \pm 2^{\circ} \mathrm{C}\right.$ and $65 \%$ R.H)

\begin{tabular}{|c|c|c|c|c|c|c|}
\hline \multirow{2}{*}{ food type } & \multicolumn{3}{|c|}{ Female } & \multicolumn{3}{|c|}{ Male } \\
\hline & Mean \pm SD & Max. & Min. & Mean \pm SD & $\operatorname{Max}$ & Min. \\
\hline & \multicolumn{6}{|c|}{ Incubation } \\
\hline Yeast & $3.18 \pm 0.42^{a}$ & 3.66 & 2.33 & $2.86 \pm 0.39^{a}$ & 3.33 & 2.00 \\
\hline \multirow[t]{2}{*}{ Lanshon } & $3.56 \pm 0.38^{\mathrm{a}}$ & 4.00 & 3.00 & $3.30 \pm 0.43^{\mathrm{a}}$ & 3.66 & 2.33 \\
\hline & \multicolumn{6}{|c|}{ Larvae } \\
\hline Yeast & $3.89 \pm 0.54^{\mathrm{a}}$ & 4.66 & 2.99 & $3.33 \pm 1.13 b$ & 4.00 & 2.66 \\
\hline \multirow[t]{2}{*}{ Lanshon } & $4.29 \pm 0.46^{a}$ & 5.32 & 3.66 & $4.06 \pm 1.06^{a}$ & 3.66 & 2.66 \\
\hline & \multicolumn{6}{|c|}{ Protonymph } \\
\hline Yeast & $3.98 \pm 0.64^{a}$ & 4.99 & 2.66 & $3.46 \pm 0.32^{b}$ & 3.66 & 2.66 \\
\hline \multirow[t]{2}{*}{ Lanshon } & $4.33 \pm 0.48^{a}$ & 5.00 & 3.66 & $4.16 \pm 1.33^{a}$ & 4.99 & 3.66 \\
\hline & \multicolumn{6}{|c|}{ Tritonymph } \\
\hline Yeast & $4.05 \pm 0.44^{\mathrm{a}}$ & 3.99 & 3.00 & $3.36 \pm 0.40^{b}$ & 3.99 & 2.66 \\
\hline \multirow[t]{2}{*}{ Lanshon } & $3.86 \pm 0.38^{a}$ & 4.33 & 3.32 & $4.39 \pm 1.44^{b}$ & 5.32 & 3.66 \\
\hline & \multicolumn{6}{|c|}{ Total immature stages } \\
\hline Yeast & $11.92 \pm 0.75^{a}$ & 12.98 & 10.31 & $10.14 \pm 0.73^{b}$ & 10.98 & 8.98 \\
\hline \multirow[t]{2}{*}{ Lanshon } & $12.48 \pm 0.67^{\mathrm{a}}$ & 13.65 & 11.64 & $12.64 \pm 0.90^{\mathrm{a}}$ & 14.3 & 11.64 \\
\hline & \multicolumn{6}{|c|}{ Life cycle } \\
\hline Yeast & $16.51 \pm 0.99^{a}$ & 18.64 & 14.98 & $13.01 \pm 0.70^{b}$ & 13.98 & 11.64 \\
\hline \multirow[t]{2}{*}{ Lanshon } & $16.05 \pm 0.82^{\mathrm{a}}$ & 17.32 & 14.65 & $15.94 \pm 0.92^{\mathrm{a}}$ & 17.96 & 14.97 \\
\hline & \multicolumn{6}{|c|}{ Adult longevity } \\
\hline Yeast & $22.45 \pm 2.95$ & 27.00 & 16.00 & $24.8 \pm 2.18$ & 30 & 22 \\
\hline \multirow[t]{2}{*}{ Lanshon } & $21.15 \pm 1.66$ & 24.00 & 17.00 & $22.7 \pm 2.72$ & 32 & 23 \\
\hline & \multicolumn{6}{|c|}{ Life span } \\
\hline Yeast & $37.55 \pm 3.42$ & 42.31 & 29.64 & $37.81 \pm 2.16$ & 41.64 & 34.97 \\
\hline Lanshon & $37.20 \pm 1.88$ & 41.64 & 32.32 & $38.64 \pm 3.35$ & 49.96 & 37.97 \\
\hline
\end{tabular}

Means followed by a different superscript letter within each stage are significantly different 
Table (2): The generation time, pre-oviposition, oviposition, post-oviposition periods, egg/female/day of Tyrophagus neiswanderi. fed on yeast and lanshon

\begin{tabular}{|c|c|c|c|c|c|c|}
\hline \multirow{2}{*}{$\begin{array}{c}\text { Type of } \\
\text { food }\end{array}$} & \multirow{2}{*}{$\begin{array}{c}\text { Generation } \\
\text { time (days) }\end{array}$} & \multicolumn{2}{|c|}{ Oviposition period (days) } & \multirow{2}{*}{ Egg/female } & $\begin{array}{c}\text { Egg/ } \\
\text { day }\end{array}$ \\
\cline { 3 - 6 } & Pre. & Oviposition & Post. & \\
\hline Yeast & $17.75^{\mathrm{b}}$ & $2.65^{\mathrm{a}}$ & $16.90^{\mathrm{a}}$ & $2.90^{\mathrm{a}}$ & $288.20^{\mathrm{a}}$ & $13.65_{\mathrm{a}}$ \\
\hline Lanshon & $18.65^{\mathrm{a}}$ & $2.60^{\mathrm{b}}$ & $15.75^{\mathrm{a}}$ & $2.80^{\mathrm{a}}$ & $175.35^{\mathrm{b}}$ & $11.21 \mathrm{~b}$ \\
\hline
\end{tabular}

Means followed by a different superscript letter only within each period are significantly different

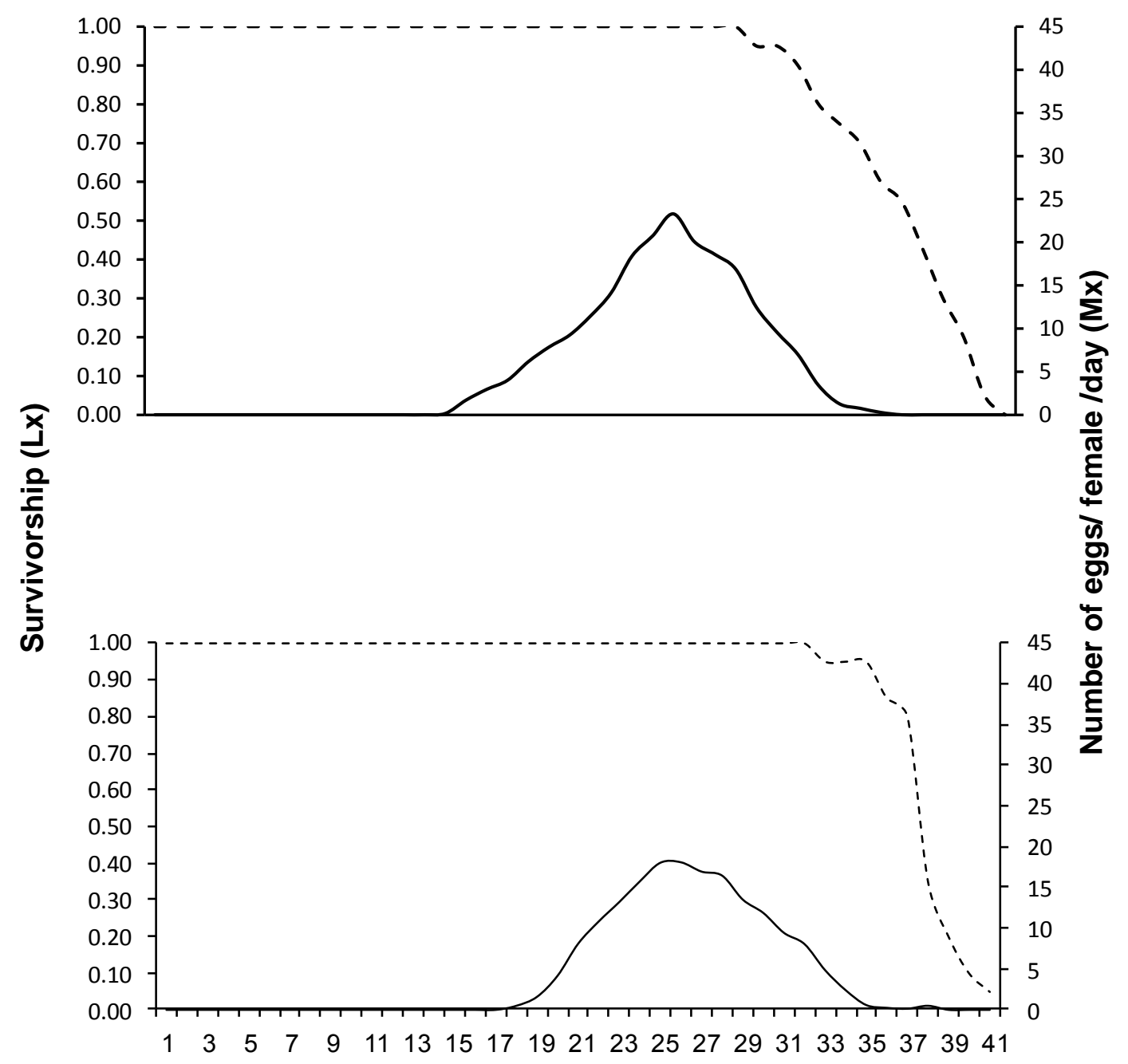

Figure (1): Survivorship (Lx) and age - specific fecundity (Mx) of the female Tyrophagus neiswanderi fed on yeast and lanshon 
These results are in partial agreement with those conducted by Sanchez-Ramos et al. (2007) who recorded that preoviposition period, fecundity and daily fecundity were adversely affected by extreme temperatures while the oviposition period increased as temperature. Male and female longevity increased as temperature decreased, but males showed significantly greater longevity than females. Additionally, this difference was greater as temperature decreased. Bahrami, et al.(2007) investigated the life history of an acarid mite, Tyrophagus putrescentiae, on Fusarium graminearum [Gibberella zeae] at 25+or-1 degrees C, $60+$ or- $5 \% \mathrm{RH}$ and a photoperiod of $16: 8$ (L:D) h. Incubation period for egg hatch, larval and nymphal periods and adult longevity were $2.22+$ or- $0.06,3.46+$ or- 0.12 , 4.84+or-0.16 and 10.05+or-0.9 days, respectively. The average life span of males and females were 22.22+or-1.21 and 19.08+or-1.37 days, respectively. Preoviposition, oviposition and post-oviposition periods were 2.22, 5.77 and 1.4 days respectively. Gross and net fecundity rates were obtained 76.2 and 23 eggs per female per generation respectively. Net reproduction rate was 12.5 female eggs per female per generation, and average daily oviposition rate was 5.7 eggs.

\section{REFERENCES}

Abo-Taka, S.M. and S.A. Allam (1997). Incidence, distribution, and ecology of ectoparasitic Acari infesting poultry farms in Menoufia Governorate, Egypt. Menofiya J. Agric. Res. 22 (2):389-403.

Bahrami, F., K. Kamali and Y. Fathipour (2007). Life history and population growth parameters of Tyrophagus putrescentiae (Acari: Acaridae) on Fusarium graminearum in laboratory conditions. Journal of Entomological Society of Iran. 26(2):7-18.

Kilpinen, O., A. Roepstorff, A. Permin, Norgaard -Nielsen G. , L. Lawson and H. Simonsen (2005).Influence of Dermanyssus gallinae and Ascaridia galli infections on behavior and health of laying hens (Gallus gallus domesticus). Br Poult Sci.46(1):26-34.

Orton, D., L. Warren and D. Wilkinson (2000). Avian mite dermatitis. Clin Exp. Dermatol.25(2):129-31.

Sanchez-Ramos, I., A. F. Alfageme and P. Castanera (2007). Reproduction, longevity and life table parameters of Tyrophagus neiswanderi (Acari: Acaridae) at constant temperatures. Experimental and Applied Acarology; 43(3):213-226.

SAS Institute (1998). SAS Users Guide. Statistics. SAS Institute, Cary, N.C. 
النواحى البيولوجية للاكاروس الأكاريدى Tyrophagus neiswanderi المربى تحت الظروف المعملية على نوعين من الغذاء الأبوى

عبد الستار محمد متولى (1) ، عوض على عبد اللهّ(1)، هاله محمد جمال الدين(2) ،

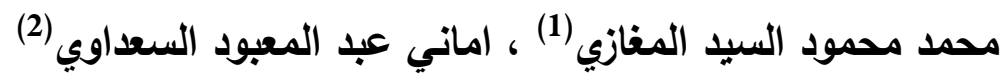
(1) قسم الحيوان الزراعى والنيماتودا كلية الزراعة جامعة الأزهر القاهرة العاني

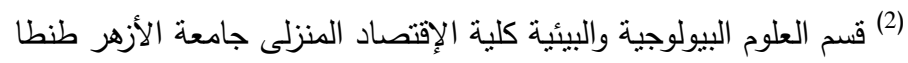

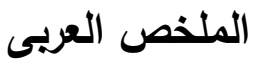
تهذف هذه الدراسة إلى تحديد ثأثير الخميرة واللحم المصنع (اللانشون) كذذاء على النواحى البيولوجية

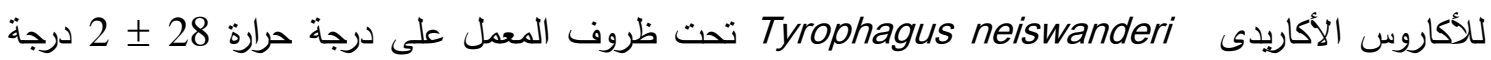

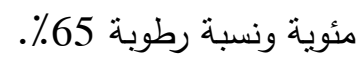

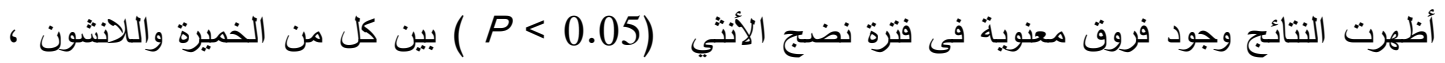

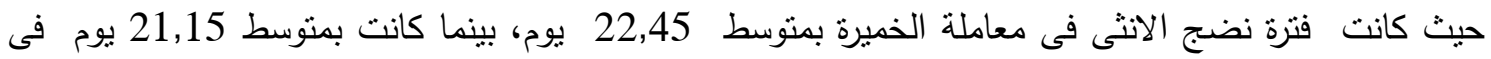

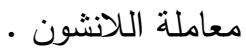
كللك يوجد إختالافات معنوية بين إناث الاكاروس (20.05 > P ) فى معدل إنتاج البيض اليومى، عند التخذية علي الخميرة واللانثون حيث كان معدل إنتاج البيض اليومى بمتوسط 13,65 بيضة فى اليوم فى معاملة الخميرة

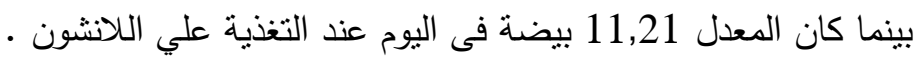


Menoufia J. Plant Prot., Vol. 1 December (2016): 139 - 145 